\title{
The Case for Clothing Construction
}

\author{
Kelley C Coffeen* and Sharon J Bartley
}

New Mexico State University, USA

*Corresponding author: Kelley C Coffeen, Assistant Professor Clothing, Textiles \& Fashion Merchandising, Department of Family \& Consumer Sciences, New Mexico State University, USA.

Received Date: February 26, 2019

Published Date: March 08, 2019

\section{Opinion}

The fashion industry employs about 1.8 million people in the United States. The industry includes high-value occupations-fashion and textiles designers, market research analysts, textile researchers and developers, computer systems developers, patternmakers, garment manufacturers, marketing, supply chain management, and wholesale buyers, along with retailers [1]. The career opportunities are diverse and expansive, with innovation evolving with an increasing demand for fashion-related skills. Although fashion careers were historically located in the fashion capitals of New York and Los Angeles, jobs in the fashion industry are now developing across the country, with design clusters appearing in the West and the South [1].

A working knowledge and understanding of clothing construction and textiles are critical to the professional success of students entering the design, production, and merchandising areas of the fashion industry. Understanding the elements and principles in constructing and altering garments also helps prepare students for this rapidly growing career field.

The goal of many fashion merchandising and design programs at the post-secondary level is to offer students a strong foundation in all of these areas.

However, students in our fashion program (and we suspect in many other programs) struggle with college-level clothing construction classes. Students lack the beginning basic construction skills that were previously taught in middle and secondary Family and Consumer Sciences (FCS) clothing classes. Today's college professor finds students with widely varying levels of expertise in clothing construction in the very same classroom.

A decline in funding at the middle and secondary schools has led to clothing construction classes being removed from the curriculum. Conversations with local public-school administrators indicate a negative perceived value for clothing construction classes and a misconception of career opportunities available to students in the fashion industry.

A review of the current literature focuses on the need for family and consumer sciences content to combat the current needs of society. We do not argue with the importance and need for this content; however, we argue that the fashion and apparel industry is robust-evidenced by double-digit sales growth driven by an expanding global market predicted over the next decade [2]. Interest in fashion and design has been heightened by technology and social media marketing, specifically in the area of customer engagement and omnichannel retailing with both male and female college students pursuing career paths in the fashion industry.

A national survey of secondary Family and Consumer Sciences (FCS) programs conducted in 2010-2012 indicated that 3,427,601 students were enrolled in FCS classes taught by 27,894 teachers [3]. However, in our state, as perhaps in other states, the focus at the secondary level has shifted to culinary arts. This narrow focus of potential FCS career and technical opportunities may unfortunately overlook careers in the fashion industry.

Based on conversations with FCS teachers and our incoming students, we are concerned about the lack of clothing construction classes currently offered in FCS classes. Our recommendation is that research be done to determine the impact of clothing construction classes in middle and secondary schools on fashion design and merchandising majors at the post-secondary level.

\section{Acknowledgement}

None.

\section{Conflict of Interest}

No conflict of interest. 


\section{References}

1. (2016) Joint Economic Committee, United States Congress. The economic impact of the fashion industry.

2. Orendorff A (2019) The state of the e-commerce fashion industry: Statistics, trends \& strategy.
3. Werhan CR (2013) Family and consumer sciences secondary school programs: National survey shows continued demand for FCS teachers. Journal of Family and Consumer Sciences 105(4): 41-45. 